\title{
Filosofia como forma de vida: variações sobre o tema a partir de Nietzsche e Sócrates*
}

\author{
Olímpio Pimenta**
}

\begin{abstract}
Resumo: Busca-se, a partir do exame dos compromissos existenciais implicados pela prática filosófica dos dois pensadores, estipular uma série de convergências entre ambos. Porque tal associação parece improvável, se se tem em vista o combate dado por Nietzsche a formulações substantivas do repertório filosófico tradicional talvez autorizadas por Sócrates, importará oferecer ao final um balanço da reflexão também quanto a isso.
\end{abstract}

Palavras-chave: Filosofia, forma de vida, Sócrates, Nietzsche.

* A redação deste artigo se beneficiou sobremaneira dos debates que se seguiram a duas apresentações públicas de versões prévias suas. A primeira ocorreu no âmbito dos Encontros Nietzsche (XLIII edição, realizada na Faculdade de Filosofia e Ciências Humanas da UFBA entre 15 e 16 de maio de 2019), a segunda no âmbito do Colóquio Nietzsche (II edição, realizada no Centro de Humanidades da UECE entre 10 e 13 de dezembro de 2019). Em ambas as ocasiões, fui acolhido com fidalguia pelos organizadores, André Itaparica e Márcio Lima na Bahia e Gustavo Costa e Ruy de Carvalho no Ceará, a quem, por essas e outras, o escrito vai dedicado.

** Universidade Federal de Ouro Preto, Ouro Preto, Minas Gerais, Brasil.

ORCID https://orcid.org/0000-0003-0200-549X

Correio eletrônico: olimpiojpneto@gmail.com 
Pimenta, $\mathrm{O}$.

São encontradas por toda a parte em Nietzsche, não obstante as oscilações que constituem um percurso filosófico bastante acidentado, reivindicações a favor de uma integração intensiva entre vida e pensamento. Partindo de um levantamento rapsódico de ocorrências expressas deste motivo ${ }^{1}$, interessa-nos determinar os traços mais próprios da articulação entre os dois domínios em termos de uma versão plausivelmente nietzschiana. A par disso, pretendemos contrastar a posição esboçada com alguns testemunhos e reflexões a respeito da forma filosófica adquirida pela vida de Sócrates, a ver se há razões suficientes para alinhá-las. Nosso propósito, vale reiterar, é saber sob que condições é possível reconhecer no autor alemão elementos de uma prática filosófica, senão comum, ao menos afim daquela levada a termo exemplarmente por Sócrates.

Dentre as inúmeras iniciativas voltadas ao enfrentamento dos problemas em jogo, destacam-se aquelas que lhes reconhecem o caráter complexo e as ambiguidades constitutivas. Avessas a um tratamento sistemático, necessariamente incompatível com as reivindicações do perspectivismo, as variadíssimas ideias do filósofo alemão a respeito da praxis de seu colega grego formam um acervo heterogêneo, cujo significado flutua em função da direção composicional que se lhes pretenda imprimir. Artes de arranjo e orquestração devem modular o material, oferecendo-lhe inteligibilidade plural, isto é, o reconstruindo segundo ordens simultâneas de significado, que resultarão sinfônicas ou cacofônicas conforme os talentos de quem as propõe.

Num espírito semelhante ao do comentário de James Porter, em que uma lista bastante representativa das referências feitas por um ao outro inclui "o primeiro filósofo da vida, e um verdadeiro amante da vida"2, mas também "um pessimista diante da vida, que procurou corrigir o ser e a realidade"3, gostaríamos de imergir na

1 Foi-me dito em tom amistoso: o procedimento se assemelha a uma navegação por um arquipélago.

2 Cf. J. I. Porter, 2009, p. 412.

3 J. I. Porter, 2009, p. 412.

64 | Cad. Nietzsche, Guarulhos/Porto Seguro, v.41, n.2, p. 63-83, maio/agosto, 2020. 
Filosofia como forma de vida: variações sobre o tema a partir de...

ambivalência que cerca a relação entre as duas figuras de modo a poder sustentar, segundo razões próprias, aquela que nos pareceu sua principal conclusão:

Foi Sócrates, Nietzsche diz, quem primeiro desenvolveu um mecanismo para abordar a qualidade das ações através da simples questão, 'Porque?' Em outras palavras, a realização filosófica de Sócrates foi propor questões sobre valor para lidar com ações investigando o valor relativo da razão e dos instintos em conexão com aquelas ações. Mesmo que Nietzsche discorde da desvalorização socrática definitiva dos impulsos instintivos para a ação, ainda assim ele reconhece que Sócrates foi, no mínimo, o primeiro a identificar ambas as fontes racional e irracional da ação $0^{4}$.

Isto porque, para além de trajetórias biográficas cujo valor e sentido são indecidíveis, parece que ambos prepararam a terra para o mesmo cultivo, provendo ao público a chance de viver vidas examinadas, não obstante a inelutável diferença que deve reger os resultados possíveis—que, no caso dos dois, se avultam até a dimensão de autênticos modelos culturais contrastantes.

Ainda a título preliminar, convém considerar que os critérios que apoiam a periodização habitual da obra de Nietzsche são de ordem temática antes que estilística. Pressupõem um desenvolvimento tético, que passaria não apenas por variação nas ênfases dadas aos objetos do pensamento e por deslocamentos teóricos estratégicos, mas inclusive por mudanças em meio às quais poderíamos constatar concepções discrepantes em termos de programa para a pesquisa filosófica. Há circunstâncias em que a letra do texto parece proibir leituras alternativas, como é o caso diante do anúncio feito ao início do conjunto de escritos que integra um putativo período intermediário, de acordo com o qual uma filosofia histórica, a ser daí em diante buscada, "não se pode mais conceber como distinta da ciência natural, o mais novo dos métodos filosóficos" (MA I/HH I, 1,1. KSA 2.23).

4 J. I. Porter, 2009, p.421. 
Pimenta, $\mathrm{O}$.

Todavia, às voltas com um que declara que "uma coisa sou eu, outra são meus escritos" (EH /EH, Por que escrevo livros tão bons, 1, KSA 6.298), mas que também adverte seu leitor quanto ao fato de que "temos de continuamente parir nossos pensamentos em meio a nossa dor, dando-lhes maternalmente todo o sangue, coração, fogo, prazer, paixão, tormento, consciência, destino e fatalidade que há em nós" (FW/GC, Prólogo, 3. KSA 3.349), somos instados a procurar uma reconstrução mais do que textual de seus propósitos e procedimentos filosóficos, sob risco de não os entendermos bem. Porque os produtos literais do pensamento não revelariam nem esgotariam seu processo de criação, importa ao intérprete explorar as mediações que os tornariam, ou não, contínuos e compatíveis entre si. Sabe-se que Nietzsche não se furta a meditar sobre o ponto, embora a restituição de suas alegações a tal respeito não seja, por si só, suficiente para decidir nem sobre o que no fundo são esses escritos nem sobre quem no fundo ele é. Aliás, pode até ser que não exista fundo nisso e naquilo e que o que mais conta é entrar em relação com isso e aquilo sem preocupação com eventuais fundamentos. Mesmo assim, impõe-se a nós a tentativa de explicitar se, e sob que condições, vida e pensamento podem se implicar de modo estrito e fecundo, uma vez que isso consta da pauta filosófica do autor, além de acarretar consequências consideráveis para nossa prática.

Que o vínculo entre vida e pensamento deve ser examinado e estimulado, pois se manifesta mesmo à revelia da consciência do pensador a respeito de si mesmo__"toda grande filosofia foi, até o momento, a confissão pessoal de seu autor, uma espécie de memórias involuntárias e inadvertidas" (JGB /BM 6, KSA 5.19-20) -, eis algo que Nietzsche sempre admitiu e defendeu. Já na virada dos anos 1860 para os 1870, enquanto militante da causa wagneriana, ele deu uma amostra um tanto penosa disso, subordinando o curso de sua inteligência do mundo a uma aliança aparentemente estranha ao seu temperamento e intuições. Os deveres da lealdade foram cumpridos 
Filosofia como forma de vida: variações sobre o tema a partir de...

com brio e "O nascimento da tragédia", bem como suas releituras feitas ao longo do tempo, dão um testemunho acabado disso. Os problemas ali ventilados e a perspectiva adotada para sua abordagem aparecem sobrecarregados por influência alheia, formulados segundo orientação alheia, voltados para soluções que depois dificilmente se conciliarão com o que Nietzsche pensa por si mesmo. Mas sua vida de então, e mesmo a vida ela mesma, serão pensadas muito mais livremente por ele apenas adiante, e as incursões metafísicas da ocasião - "toda essa metafísica de artistas [que] pode-se denominar arbitrária, ociosa, fantástica" (GT /NT, Prólogo, 5, KSA 1.17) - darão lugar a uma disciplina de pensamento rigorosa e a remanejamentos conceituais notáveis. A propósito, já se viu nisso a retomada de um espírito cético e esclarecido, presente desde a formação filológica e a frequentação de Lange, embora nos pareça que a iniciativa é também congruente com intenções ainda mais primitivas do autor, atuantes desde o tempo de sua formação escolar em Pforta. ${ }^{5}$

Se, ao longo da obra, conceitos-chave são reconfigurados para atender às novas direções da pesquisa, não parece que a disposição nietzschiana a respeito das tarefas que definem a filosofia siga caminho análogo. O abandono da "necessidade metafísica" não transforma Nietzsche em um outro, mas apenas o alivia de obrigações emprestadas, devolvendo a ele a chance de gestar questões segundo injunções próprias. Formado no ambiente da filologia clássica, mas avesso ao escolasticismo acadêmico e à erudição autorreferente, seu pensamento vai, desde as Considerações Extemporâneas, aprofundar dramaticamente a questão de seus nexos com a vida. Não é o caso dizer que isso estava ausente do livro de estreia mas, sim, que doravante pode-se prosseguir na sua exploração sem o embaraço do dionisíaco entendido segundo uma grade dualista, refém de realizações artísticas baseadas na música, cujo significado resta agora discutível.

5 A este respeito, $c f$. F. Lemos, 2015. 
Pimenta, $\mathrm{O}$.

Nesse sentido, encontramos no escrito sobre a História e a Historiografia, desde o título, o cultivo de preocupações voltadas para aqueles nexos. Mais importante, encontramos ali passagens que iluminam em cheio o tema em discussão. Com efeito, depois de tomar posição a respeito da "doença histórica", capaz de levar ao desespero aquele que dela extrai todas as consequências axiológicas, a reflexão se lança em busca de antídotos. Encaminha-se a atenção para a ideia de uma cultura autêntica, "designada [...] com algum direito como a unidade do estilo artístico em todas as expressões da vida de um povo" (HL /Co. Ext. II, 4, KSA 1.274) que só pode ser criada sob a proteção de uma atmosfera a-histórica, na qual a dimensão irredutível do devir de todas as coisas é acolhida e elaborada em termos humanamente toleráveis. A dissolução de tudo o que existe no tempo pode ser enfrentada e até mesmo tornar-se motivo de alegria ao abrigo de certos horizontes, no interior dos quais a vida se faz desejável. Em situações extraordinárias, esta vida agora acolhida, nutrida e feita apta ao cultivo da excelência pode também gerar filosofia. O conhecimento mais difícil, embalado por elevadas expectativas quanto à relação entre verdade e justiça, quer se dedicar ao serviço da vida boa e à dignificação de algo que, em si mesmo, é frágil, sujeito a toda sorte de vicissitudes e cujo caráter tende a resvalar para o trágico.

No contexto desse debate, Nietzsche reage contra a artificialidade que rege tanto a eleição dos assuntos a se estudar quanto a escolha dos valores aos quais se pretende honrar com tais estudos. Alguns dons da modernidade - acesso liberal a todas as fontes bibliográficas imagináveis, disponibilidade de todos os modelos de vida moral experimentados pela civilização, instituições de ensino voltadas à produção massiva de material para divulgação e consumo - parecem abusivos a seus olhos. Tudo isto seria, exatamente, função de um empobrecimento da vida, de uma indiferença um tanto ao quanto estúpida frente ao enraizamento vital da esfera da cultura. 
Filosofia como forma de vida: variações sobre o tema a partir de...

Arrisca-se mais ainda quando a filosofia entra em jogo: "Em que condições inaturais, artificiais e em todo caso indignas se encontra, em uma época que padece da cultura geral, a mais veraz de todas as ciências, a honesta e nua deusa filosofia!" (HL/Co.Ext. II, 5, KSA 1.282). Acontece então um desvirtuamento radical dos investimentos em seu campo que, se comparado com o estado do assunto entre os antigos, pode até envergonhar o trabalho filosófico feito a partir do advento da época moderna. Lá não se definia o que pensar considerando as preferências da estação ou a conveniência de quem financia, mas levando em conta exigências envolvendo a maneira de viver e, por assim dizer, os sins e nãos que decidem o rumo das práticas individuais e comunitárias em função da experiência do pensamento e da procura da verdade. Entrementes, tendo o pensamento das escolas helenísticas sido tomado como referência, é inevitável ponderar que este Nietzsche está se reportando, de algum modo, a Sócrates, pai espiritual de todos os desdobramentos filosóficos ligados a essas escolas. Se, para elas, a exortação socrática ao pensamento não se confina ao aprendizado de dogmas e doutrinas ditados por terceiros, deixando intacto o modo de ser de quem se expõe a pensar filosoficamente, parece que estamos numa companhia que considera as coisas de um ângulo convergente.

Um tal elogio do pensamento antigo, feito menos a partir de uma coleção de seus resultados doutrinais do que de sua incidência edificante sobre a vida, pode à primeira vista soar desencontrado da já mencionada adesão programática do filósofo às modernas ciências naturais. Se o fiel da balança fosse uma questão de método, não haveria continuidade possível entre gêneros culturais tão afastados um do outro, o que teria exigido de Nietzsche uma guinada radical se estivesse pretendendo alinhar seu pensamento às ciências. Mas é estranho considerar o caso como uma conversão desse tipo - afinal, filosofemas não são testáveis empiricamente, mesmo guardando relevância prática decisiva, e retidão intelectual e argumentativa 
Pimenta, $\mathrm{O}$.

não se aprende exclusivamente com a ciência -, mesmo admitindo que a incorporação de técnicas e subsídios oriundos de quase todos os domínios científicos florescentes tenha sido procurada por ele. Dessa forma, o que se acompanha no decurso de sua produção é um diálogo, cerrado e instrutivo, com as ciências naturais suas contemporâneas, embora guiado por um repertório que ultrapassa o que elas propõem e cujo fulcro é a própria relação entre a pesquisa da verdade e uma vida válida.

Nesse sentido, é oportuno revisitar, ainda no registro dos escritos ditos intermediários, a inspirada meditação sobre tópicos ligados ao problema do conhecimento. Previamente ensaiadas em 1873 em Sobre verdade e mentira, as ideias de Nietzsche sobre a matéria recebem tratamento mais consistente, por exemplo, nas discussões iniciais do terceiro capítulo de $A$ gaia ciência, onde se destaca a exposição sobre a origem do conhecimento feita no aforismo 110. Ali, a questão concerne originalmente ao modo segundo o qual se articulam as relações entre a experiência vital de grupos humanos pré-históricos e suas expectativas sobre os poderes do intelecto. Dominados pela urgência dos esforços voltados para sua sobrevivência, tais grupos aceitavam como certo apenas aquilo que se provasse imediatamente útil. Com base nisso, constituíram um elenco de crenças duras, testadas na luta diária, que terminaram por formar algo como um patrimônio comum aos membros da espécie, no interior do qual constam artigos como a existência de coisas duráveis - almas individuais e indivisíveis, por exemplo -, de coisas iguais, de coisas que são o que aparentam ser, enfim. Ao lado disso, figuram também sólidas convicções sobre a liberdade do querer e a natureza do bem, definido ainda estritamente segundo o interesse.

Essa modalidade não examinada de erros metafísicos de raiz moral persistiu hegemônica na mentalidade coletiva até que uma nova e estranha disposição para duvidar, questionar e esperar, ao invés de agir, entra em cena, pela mão dos pensadores pré-socráticos. 
Filosofia como forma de vida: variações sobre o tema a partir de...

Processos de verificação, já vigentes no âmbito judicial, coexistem então com um pensamento ainda fraco, dadas suas escassas chances de inserção cotidiana, ocupado com a elaboração de representações laicas da verdade. Contudo, a força do conhecimento cresce à medida em que seus produtos passam a se mostrar aplicáveis às questões práticas da vida. Já em plena vigência da história, cidades permitem que as atividades humanas ganhem uma complexidade nunca vista, favorecendo a existência de estratos sociais em que as indagações sobre a verdade são revestidas de grande apelo. Chegamos, assim, a uma nova etapa do processo, circunstância em que o conhecimento finalmente se prova um poder digno de cultivo, lado a lado com aqueles antiquíssimos artigos de fé há muito sedimentados. Diante disso, ergue-se uma pergunta crucial: uma vez que a incorporação de erros e verdades só funciona no interior de alguma forma viável de vida, seria possível uma forma de vida em que o exame de tudo segundo expectativas críticas funcionasse? Em suma: até que ponto é suportável a incorporação da verdade?

Com tal problemática em mente, cabe lembrar uma célebre passagem do Laques de Platão (187e-188a), na qual a prática filosófica socrática é reportada por um de seus interlocutores. Sem entender bem o que estava em andamento, Lisímaco pergunta a Nícias onde aquela investigação sobre a coragem iria se deter, recebendo como resposta que a coisa toda convergiria para uma espécie de prestação de contas da parte de quem estivesse sendo examinado a respeito de suas escolhas e justificativas, feitos e malfeitos, ditos e omissões, que tenderia a culminar numa revisão crítica radical de sua vida atual e pregressa. Repudiando diretamente o recurso à opinião como fonte legítima de respostas à sua interpelação, o personagem Sócrates parece chamar para si tarefa semelhante à esposada por Nietzsche séculos depois, conduzindo seus interlocutores ao exame de si mesmos, no sentido do estabelecimento da afinidade ou não de sua vida com o processo da verdade. Fica determinado, na prática, que o 
Pimenta, $\mathrm{O}$.

reinado absoluto da crença, que prestou tantos serviços fundamentais à espécie, pode coexistir com uma forma de viver refinada pela dúvida, segundo a qual o exercício constante do pensamento crítico é capaz de se provar, para além do mero cálculo de vantagens, um honroso dever de consciência.

Sem discriminar qual seria o alvo prioritário do aforismo aludido - se a civilização ocidental moldada pela revolução científica ou se qualquer um de nós enquanto vivente -, parece pertinente admitir que a incorporação da filosofia ao curso da vida é um ponto de coincidência entre o que se lê ali e o mérito daquilo que Platão atribui a seu mestre. Se há um denominador comum a todas as formas da vida filosófica tentadas desde a antiguidade, ele está no entrelaçamento entre a prática sem descanso do exame racional e todas as demais práticas que preenchem a existência de indivíduos e comunidades, que poderão daí em diante ser tocados pelo amor à sabedoria, que neste caso é também amor à verdade. Mesmo aos "mestres da finalidade da existência" e seus discípulos é prometido um futuro em que riso e seriedade se sucederão sem conflito, graças à ideia de um gênero cultural novo, uma gaia ciência. Ora, também Xenofonte assegura que, em plena prática dialógica socrática, brincadeira e probidade se copertencem ${ }^{6}$. Vale acrescentar que a nobreza necessária à formação de uma consciência intelectual pode encontrar na paixão do conhecimento seu melhor palco, pouco importando se da atuação se concluir pelo risível inerente às pretensões a respeito da determinação de um sentido global para a existência. Ao que se saiba, tampouco o irônico Sócrates se deixou seduzir por ficções relacionadas ao absoluto.

As perspectivas e paisagens da filosofia nietzschiana estão sempre mudando. Ciente de que a retidão é um bem escasso, ele se dedica nos anos de 1880 à criação de experimentos de pensamento capazes de mobilizar as paixões do público leitor em prol de sua

6 Nesse sentido, por exemplo, lê-se em Xenofonte, ao termo de uma passagem: "e era assim que as brincadeiras se misturavam com as conversas sérias". (Banquete, IV, 29).

72 | Cad. Nietzsche, Guarulhos/Porto Seguro, v.41, n.2, p. 63-83, maio/agosto, 2020. 
Filosofia como forma de vida: variações sobre o tema a partir de...

adesão a uma forma filosófica de vida. Psicólogo perspicaz, Nietzsche sabe das dificuldades encerradas pela exigência do exercício de uma consciência intelectual em um mundo dominado por imperativos pragmáticos. Sabe, portanto, que uma ruptura com a vida guiada pela opinião, pública ou privada, depende de experiências vitais que a maioria sequer vislumbra. Assim como Platão, ele entende ainda que o uso de imagens exerce apelo poderoso sobre a audiência, e que mitos e narrativas quase sempre moldam a visão que as pessoas têm da realidade. Como a ciência devota seu trabalho comunitário e institucional à produção de modelos matematizados passíveis de teste empírico, resultando por isso distante dos sentimentos da maioria, importa a quem queira afetar o público a favor da verdade criar cenários em que o exame da vida se imponha. Os chamados grandes temas da filosofia nietzschiana, formulados à época, articulam-se a esta opção estratégica. Acompanhando, por exemplo, as peripécias do personagem Zaratustra, o leitor é instado a rever a sério sua vida moral, e em particular sua situação relativamente ao ressentimento. Uma superação do mais que incômodo estado de ressentimento, uma transformação de afetos ressentidos em afetos sãos, promovida pelo processo de aprendizado da afirmação do "eterno retorno", abre espaço para todo tipo de vivências inusitadas. Porque obtidas em nome da livre investigação de si, essa superação e essa transformação atraem para a verdade, provando ao seu cultor o quanto vale prosseguir dedicado a ela em sua vida.

A produção tardia de Nietzsche, tendo incorporado o pensamento genealógico e o perspectivismo - para nós existentes em forma embrionária desde o escrito sobre a tragédia -, se alterna entre a concisão da escrita em aforismos e narrativas conceituais mais abrangentes. Ligada, nos dois casos, ao ensaísmo, a prosa nietzschiana do período cuida de consolidar as posições teórico-vitais amadurecidas desde os primeiros textos. Tendo problematizado, como nenhum outro antes, a "vontade de verdade", o filósofo provou-se, 
Pimenta, $\mathrm{O}$.

sem paradoxo, um adepto rigoroso da investigação sob esta mesma bandeira ${ }^{7}$. Embora duvide das possibilidades de posse da verdadeira verdade, ele oferece a quem quiser um relato bastante defensável sobre as origens humanas desta demanda. Neste movimento, ele lança luz sobre as condições em que o móvel "verdade" figura como ingrediente principal de nossa vida psíquica e política, ainda que nos formatos não exatamente examinados das verdades religiosa, moral ou artística.

Cabe referir uma última ocorrência da preocupação em vincular vida e pensamento, dado o uso um tanto impressionante em sua enunciação de um vocabulário reconhecivelmente socráticoplatônico. No âmbito da exposição sobre os vínculos entre ideal ascético e filosofia, após elucidar o franco contraste vigente entre as condições da verdade em sua forma filosófica e os fundamentos para a verdade em sua forma tradicional, Nietzsche opõe antigos e modernos quanto às suas respectivas atitudes em face de Deus, da natureza e do que é propriamente humano. Em nós, gente moderna, o exame racional parece não respeitar qualquer objeto, aplicando-se a tudo sem reservas, de modo violento e impiedoso. Apesar disso, parece possível que a iniciativa tenha futuro, pois mesmo agora, vivendo uma vida examinada em termos tão radicais, talvez nos tornemos, finalmente, mais dignos dela: "Violentamos a nós mesmos hoje em dia, não há dúvida, nós, tenazes, quebra-nozes da alma, questionadores e questionáveis, como se viver fosse apenas quebrar nozes; assim nos devemos tornar cada vez mais passíveis de questionamento, mais dignos de questionar, e assim mais dignos talvez-de viver?..." (GM/ GM, III, 9, KSA 5.359). É inevitável que uma tal declaração chame à memória um dos lugares comuns mais duradouros e eloquentes associado à exortação socrática, de acordo com o que uma vida sem exame não é digna de ser vivida ("Apologia de Sócrates", 38a). Em

\footnotetext{
7 Veja-se novamente, por exemplo, a segunda extemporânea: “verdade não como posse egoísta do indivíduo, mas como a licença sagrada de mover todas as barreiras de posse egoísta; verdade, em uma palavra, como justiça universal e não algo como caça e satisfação de um caçador". (HL/Co.Ext. II, 6, KSA 1.286).
}

74 | Cad. Nietzsche, Guarulhos/Porto Seguro, v.41, n.2, p. 63-83, maio/agosto, 2020. 
Filosofia como forma de vida: variações sobre o tema a partir de...

que pesem as reticências postas por Nietzsche ao final da frase, é razoável considerar que para ele, mesmo sob condições extremas, o pensamento que recusa soberania à vida não examinada ainda é uma atividade capaz de nos dignificar.

Parece, assim, que a ocupação com a verdade guiada pela máxima "lancemo-nos ao proibido" (EH /EH, Prólogo, 3, KSA 3.259) só é conveniente a um espírito tornado livre, senhor de seu medo quanto aos perigos aí implicados. Mas cumpre insistir no esclarecimento dos termos deste compromisso. Se se toma a verdade como um repositório cristalizado de respostas, dificilmente os dois pensadores se ajustariam ao papel de pesquisadores seus, de filósofos a justo título. Diversamente, se se toma a verdade como nome de um processo, como rubrica genérica sob a qual transcorre a ação de interrogar o mundo e de inventar nele um caminho para a honesta tentativa de discriminação entre coisas provadas e coisas incertas, sempre segundo nossos melhores achados em termos de inteligibilidade, podemos reencontrar em seu âmbito a companhia de ambos.

Se o que foi colhido até agora nos autoriza a bancar a existência de afinidades entre Nietzsche e Sócrates a propósito da filosofia como forma de vida, resta abordar a série de indicações em contrário disseminadas pelo primeiro em seus escritos. Como se sabe, o "caso Sócrates" foi tratado pelo alemão de modo quase obsessivo, comportando versões diferentes conforme a ocasião $0^{8}$. O motivo das suas recriminações não é impiedade nem corrupção da juventude, mas devoção cega à razão, em detrimento do corpo, da arte e da tragicidade. Nesta versão as ilusões socráticas quanto ao poder do pensamento teriam sido as de um idealista, de alguém convicto de que o sentido último da realidade será desvendado pela investigação racional. Daí se seguiriam o desprezo ao corpo e aos sentidos e a recusa de legitimidade ao viés trágico na consideração do valor da

8 A esse respeito, $c f$. Wander de Paula, 2009. 
Pimenta, $\mathrm{O}$.

existência. A tonalidade dominante na trajetória do filósofo seria mórbida, e o sinal mais nítido disso seriam suas palavras finais, tal como apresentadas por Platão.

Enigmática por si mesma, esta sentença do Sócrates platônico permite um sem número de leituras ${ }^{9}$. $\mathrm{O}$ reconhecimento, expresso pelo personagem em sua última fala, de que seria necessário pagar a obrigação devida por uma cura, geralmente é visto como sinal de que a morte teria vindo livrá-lo da doença de viver. Mas nada impede que se admita que, em tal circunstância, ele tenha dito uma palavra irônica - no mínimo, tempo teve para ruminá-la. Nesse sentido, novamente a orientação de Xenofonte pode ser de valia. Em sua "Apologia de Sócrates" lê-se o seguinte, atribuído ao personagem:

“ [...] se a minha idade continuar a prolongar-se, sei que será necessário que sofra as consequências da velhice: ver pior, ouvir menos, ser mais lento a aprender e mais esquecido do que aprendi. Ora, se tiver esta percepção de que me tornarei mais fraco e se tiver de me censurar a mim mesmo, como é que poderei continuar a viver com gosto?"10

O teor do dito reportado por Platão pode, sob esta luz, receber uma inflexão inesperada: não se trataria mais de uma cura metafórica, relativa ao fenômeno global da vida, mas apenas da libertação de um estado geralmente deplorável, associado ao enfraquecimento e à instalação de limitações irreversíveis. Este Sócrates prosaico e sensato teria tido ainda humor para saudar, como efeito colateral do cumprimento de sua sentença, o fato de não mais precisar de se preocupar com o declínio e, por assim dizer, ter assegurada para si uma saída menos lamentável da condição de vivente.

Decerto não se pode ajuizar em bloco sobre o valor da vida, uma vez que somos parte interessada, comprometida com sua

\footnotetext{
9 Por sua engenhosidade, destaco a leitura de Glenn Most, segundo a qual o sacrifício do galo seria devido à cura do próprio Platão, que assim fez presente sua assinatura na cena da morte de seu mestre mesmo não tendo estado lá. Cf. Glenn Most,1993.
}

10 Xenofonte, Apologia de Sócrates, I, 7.

76 | Cad. Nietzsche, Guarulhos/Porto Seguro, v.41, n.2, p. 63-83, maio/agosto, 2020. 
Filosofia como forma de vida: variações sobre o tema a partir de...

manutenção e expansão em nossos próprios termos. Porque não é possível tomar distância desses processos sem sucumbir, mais vale abraçar, na imanência, a tarefa mais difícil: a construção de uma hierarquia entre maneiras de viver cujo topo esteja reservado para aquelas que acrescentam vitalidade à vida em sua efetividade. Motivo central do pensamento nietzschiano, esta avaliação em escala colossal aparece associada à "transvaloração de todos os valores", experimento civilizacional que aspira a promover a afirmação. Cumpre conhecer como vivem e viveram as culturas em seus próprios tempo e lugar, de modo a apreciar com propriedade as tábuas de valores em que se consagraram suas opções existenciais fundamentais. Pouco importando por princípio se tais repertórios axiológicos se apoiam na religião, na arte, na ciência, no mercado, na indústria ou no que mais for, interessa pensar que tipo de relação com o mundo é facultado e desejado a partir deles. De acordo com o juízo de Nietzsche, um fator deve sempre ser considerado: o papel que se atribui aos além mundos na economia espiritual de cada cultura. Quanto mais importância se dá à fantasia de uma vida perfeita fora daqui, fora deste mundo, maiores as chances de estarmos em presença de uma perspectiva refém do sofrimento; ao contrário, quanto mais se adere às realidades mundanas, terrestres, mais provável é que estejamos às voltas com uma perspectiva que equacionou o sofrimento de forma a torná-lo um estímulo, e não uma objeção, à afirmação.

Essas cogitações permitem uma última comparação entre as figuras de Sócrates e Nietzsche. Nem mesmo na versão platônica o primeiro personagem recusa a vida que leva em favor de outra coisa. Seu empenho é constante a favor de uma reforma moral instruída pela busca da verdade, mas nunca se lê que isto depende, para ele, de segundas ou terceiras navegações. Aliás, a diversidade das orientações que partem dessa diretriz favorece uma corroboração indireta da lição: Sócrates é também, a justo título, figura exemplar para os movimentos cínico, cético e epicurista, aos quais nenhum 
Pimenta, $\mathrm{O}$.

outro mundo é necessário. Certas filosofias prosperam rejeitando tal recurso e, pesando o exposto até aqui, o próprio pensamento de Nietzsche pode contar entre elas.

Em vista dos objetivos deste exercício cumpre, à guisa de arremate, indicar em largos traços algum elemento que permita discernir os muitos Sócrates e socratismos, de modo a especificar o alcance das observações de Nietzsche a respeito de uns e outros. Ao Sócrates ultra racionalista e tendente à especulação que se depreende, por exemplo, tanto do Fédon quanto do Crepúsculo dos ídolos, cabe contrapor o mestre de Antístenes e Diógenes, também mentor putativo de $A$ gaia ciência - um sujeito ocupado com o cultivo de uma vida excelente na cidade, não obstante sua relação ambígua com ela. Se o socratismo historicamente hegemônico segue sendo otimista e ingênuo, dada sua confiança pia nos poderes da razão, um socratismo vacinado contra isso, exercitado nas práticas da interrogação filosófica e historicamente calibrada, pode muito bem ser aquele com o qual Nietzsche se sentiria à vontade. Afirmar a existência não é prerrogativa exclusiva de qualquer gênero ou iniciativa culturais, pois mesmo as artes, aliadas nietzschianas permanentes, podem promover tanto a vida quanto seu oposto. Se é plausível uma versão em que a filosofia praticada por Sócrates favoreça um uso mitigado da razão, permitindo reconhecer no socratismo das escolas helenísticas um caminho viável para a articulação em estudo, talvez seja o caso de ver no melhor de Nietzsche a imagem de um frequentador extemporâneo seu. Nessa linha, quem sabe o significado mais importante do pensamento de um e outro filósofos, para lá das teses e posicionamentos concretos que podem ser atribuídos a eles, esteja na invenção da verdade e na iniciativa a favor de sua incorporação pela vida? 
Filosofia como forma de vida: variações sobre o tema a partir de...

$$
* * *
$$

Um estudo ocupado com os nexos entre vida e pensamento resultaria mais incompleto do que convém se não mencionasse, mesmo que de passagem, algumas coincidências entre o pensamento de Nietzsche e certos desenvolvimentos da pesquisa científica contemporânea. Tendo definido "o afeto humano, o mundo das emoções e sentimentos" como principal tema de seu livro "A estranha ordem das coisas" "11, parece-nos que o pensador português António Damásio retoma, deliberadamente ou não, um programa de trabalho bastante parecido com aquele que Nietzsche executa a partir de Humano, demasiado humano. Lê-se em Damásio que,

em essência [...] a atividade cultural começa e permanece profundamente alicerçada em sentimentos [e] precisamos reconhecer a interação favorável e desfavorável dos sentimentos com o raciocínio se quisermos compreender os conflitos e as contradições da condição humana ${ }^{12}$.

A primeira impressão é que a tarefa de determinar uma "química dos conceitos e sentimentos" enfim encontrou interlocução junto a uma tradição naturalista madura, apta a mapear os labirintos da alma em sede mental e a explicitar em termos evolucionários os vínculos que os indivíduos tramam de si para si, entre si e outros indivíduos e entre si e seus grupos - famílias, comunidades restritas e comunidades ampliadas, que abrangem desde o bairro até o planeta.

Mais impressionante ainda é que o protagonista conceitual da narrativa de Damásio é o imperativo da homeostase, conjunto de processos segundo o qual a regulação da vida, desde o funcionamento de organismos elementares até o de sociedades complexas, humanas ou não, é descrita em termos da busca por condições que permitam

11 Cf. A. Damásio, 2018.

12 A. Damásio, 2018, p.13.

Cad. Nietzsche, Guarulhos/Porto Seguro, v.41, n.2, p. 63-83, maio/agosto, 2020.| 79 
Pimenta, $\mathrm{O}$.

aos viventes "perdurar e prevalecer"13, estendendo sua presença na existência. Constata-se que a vida - não qualquer ente genérico, mas aquilo efetivamente experimentado pelos que dela participam - procura, em todas as situações, o que favorece sua continuação, de preferência em termos de permanência e expansão. Sentimentos básicos, polarizados entre sofrimento e bem estar, são os catalizadores da atuação dos viventes, ainda aqui humanos ou não, sinalizando, segundo diferentes graus, como eles devem viver para atingir seu melhor ${ }^{14}$.

Bem entendido: o sucesso dos processos homeostáticos não é apresentado como finalidade universal subjacente a todas as intenções dos viventes ou princípio universal de avaliação de sua trajetória no mundo, mas como um dispositivo de medida que permite apreciar, ao nível das interações ao mesmo tempo mais complexas e sutis, os graus de esforço do que vive e o saldo de sua ação em termos eminentemente vitais. Salvo engano, algo estritamente análogo é intuído por Nietzsche em declarações como a que se segue, em que o sentimento de potência fornece a cifra para uma semiótica de vasto emprego:

Todo animal, portanto também la bête philosophe, busca incessantemente um optimum de condições favoráveis em que possa expandir inteiramente sua força e alcançar o seu máximo de sentimento de poder; todo animal, também instintivamente e com uma finura dos sentidos que está 'acima de toda razão', tem horror a toda espécie de intrusões e obstáculos que se colocam ou poderiam colocar-se em seu caminho para o optimum (não

13 Sobre esta expressão, o autor esclarece: “A parte do imperativo homeostático que diz respeito a 'perdurar' é clara: ele permite a sobrevivência e é considerado indiscutível, sem nenhuma referência ou reverência específica quando se fala em evolução de qualquer organismo ou espécie. A parte da homeostase que diz respeito a 'prevalecer' já é mais sutil e raramente reconhecida. Ela assegura que a vida é regulada não apenas em uma faixa compatível com a sobrevivência, mas também conducente à prosperidade, a uma projeção da vida no futuro de um organismo ou espécie". A. Damásio, 2018, p. 35, grifo nosso.

14 Ficamos tentados a reconhecer nessas conclusões afinidade com aquilo que Freud alega em sua obra-prima: "Se supusermos, de maneira bem geral, que o motor de todas as atividades humanas seja a aspiração a duas metas confluentes, a utilidade e o ganho de prazer, então o mesmo deve valer para as manifestações culturais aqui mencionadas [isto é: sistemas religiosos, especulações filosóficas e formulações do ideal dos seres humanos], embora isto só seja facilmente visível nas atividades científica e artística.” Cf. S. Freud, 2020, p. 343.

80 | Cad. Nietzsche, Guarulhos/Porto Seguro, v.41, n.2, p. 63-83, maio/agosto, 2020. 
Filosofia como forma de vida: variações sobre o tema a partir de...

falo do caminho para a 'felicidade', mas do caminho para o poder, para o ato, para a mais poderosa atividade, na maioria dos casos, realmente, seu caminho para a infelicidade). (GM/GM, III, 8, KSA 5.352).

Se é necessário pensar o problema do valor e determinar a hierarquia dos valores, nossas melhores escalas podem agora ser calibradas em termos homeostáticos ou, se se preferir, em termos de uma teoria do sentimento de potência. Tudo isso aceito e obtida a matéria para exame segundo procedimento genealógico - vale assinalar que, em Damásio como em Nietzsche, mediações tanto especulativas quanto empíricas dissolvem as oposições cristalizadas entre natureza e cultura, mente e mundo, fato e norma, corpo e alma - Sócrates e Nietzsche podem finalmente contar como instrumentos de medida, sensores rigorosos e versáteis, que nos permitem estimar quais são e como, quando e onde acontecem as vidas verdadeiramente dignas de serem vividas.

Philosophy as a Form of Life: Variations on the Theme Stemming from Nietzsche and Socrates

\begin{abstract}
We aim, starting from the examination of the existencial commitments implied by both thinkers' philosophical practice, to define a series of convergences between them. Once this association seems unlikely, considering the combat fought by Nietzsche against substantial formulations pertaining to tradicional philosophical repertoire maybe authorised by Socrates, it will matter to offer a final balance on the reflection also about that.
\end{abstract}

Keywords: Philosophy, Form of life, Socrates, Nietzsche. 
Pimenta, 0 .

\section{Referências}

DAMASIO, António. A estranha ordem das coisas: as origens biológicas dos sentimentos e da cultura. São Paulo: Companhia das Letras, 2018.

DE BRITTO, Fabiano Lemos. Soldados e centauros: educação, filosofia e messianismo no jovem Nietzsche, 1858-1869. Rio de Janeiro: Mauad X; Rio de Janeiro: Faperj, 2015.

DE PAULA, Wander A. O(s) Sócrates de Nietzsche: uma leitura d'O nascimento da tragédia. Campinas, SP: [s.n.], 2009. (Dissertação inédita de mestrado).

FREUD, Sigmund. O mal-estar na cultura. Trad. Maria Rita Salzano Moraes. In. O mal-estar na cultura e outros escritos. Belo Horizonte: Autêntica, 2020.

MOST, Glenn W. “'A Cock for Asclepius'.” The Classical Quarterly, vol. 43, no. 1, 1993, pp. 96-111. JSTOR, www.jstor.org/stable/639455. Accessed 25 June 2020.The Classical quarterly.

NIETZSCHE, f. Sämtliche Werke. Kritische Studienausgabe (KSA). G. Colli e M. Montinari (hrsg.). Berlim: Walter de Gruyter/Deutsche Taschenbuch Verlag, 1980. $15 \mathrm{Bd}$

. O nascimento da tragédia: helenismo e pessimismo. Trad. J. Guinsburg. São Paulo: Companhia das Letras, 1992.

. Sobre a utilidade e a desvantagem da História para a vida. Trad. André Itaparica. São Paulo: Hedra, 2014.

.Humano, demasiado humano: um livro para espíritos livres. Trad. Paulo César de Souza. São Paulo: Companhia das Letras, 2000.

. A gaia ciência. Trad. Paulo César de Souza. São Paulo: Companhia das Letras, 2001.

. Além do bem e do mal: prelúdio a uma filosofia do futuro. Trad. Paulo César de Souza. São Paulo: Companhia das Letras, 1992.

. Genealogia da moral: um escrito polêmico. Trad. Paulo César de Souza. São Paulo: Editora Brasiliense, 1987.

. Ecce Homo: como alguém se torna o que é. Trad. Paulo César de Souza. São Paulo: Companhia das Letras, 2004.

82 | Cad. Nietzsche, Guarulhos/Porto Seguro, v.41, n.2, p. 63-83, maio/agosto, 2020. 
Filosofia como forma de vida: variações sobre o tema a partir de...

PLATÃO. Apologia de Sócrates; Críton. Trad. Manuel de Oliveira Pulquério, Brasília: Editora UnB, 1997.

Laques; Eutífron. Trad. C. A. Nunes. Belém: Editora UFPA, 2015.

PORTER, James I. Nietzsche and "The problem of Socrates". In. Sara AhbelRappe, Rachana Kamtekar (Orgs). A Companion to Socrates. Oxford: Blackwell Publishing, 2009.

XENOFOnTE. Banquete; Apologia de Sócrates. Trad. Ana Elias Pinheiro. São Paulo: Annablume Clássica; Coimbra, CECH, 2011. 